\title{
PENGARUH KEBIJAKAN PROGRAM GERAKAN LITERASI SEKOLAH TERHADAP MINAT BACA PESERTA DIDIK SMA AL HUDA TUBAN
}

\author{
Atik Nihayatuzen'), Fahrur Rosikh2), Hidayatul Mufidah'), \\ ${ }^{1}$ Institut Pesantren Sunan Drajat Lamongan, Indonesia \\ 2 Institut Pesantren Sunan Drajat Lamongan, Indonesia \\ ${ }^{3}$ Institut Pesantren Sunan Drajat Lamongan, Indonesia) \\ Email: nihayayuzzain1 ${ }^{1}$ frrosikh@gmail.com², hidayatulmufidah@insud.ac.id³
}

Dikirim: 30 April 2021

Diterima: 20 Mei 2021

Dipublikasi: 31 Juli 2021

\begin{abstract}
Abstrak; Iklim literasi dalam dunia pendidikan semakin gencar disuarakan. Untuk mewujudkan Gerakan Literasi Nasional, baik di ranah sekolah, keluarga, maupun masyarakat, diperlukan strategi yang komprehensif dan terencana. Melihat akan pentingnya budaya baca dan minimnya minat baca di Indonesia pemerintah telah mencangkan gerakan literasi. Implementasi strategi tersebut dengan menciptakan Gerakan Literasi Sekolah yang dilakukan Pemerintah dalam bidang pendidikan yaitu Undang-Undang Republik Indonesia Nomor 20 Tahun 2003 tentang Sistem Pendidikan Nasional. Pada Bab III pasal 4 ayat 5, berbunyi "Pendidikan diselenggarakan dengan mengembangkan budaya membaca, menulis dan berhitung bagi segenap warga masyarakat", Membuat kebijakan tentang minat baca. Minat baca yang diharapkan tumbuh dan berkembang pada peserta didik ini, dipandu dengan adanya kebijakan gerakan literasi sekolah atau yang biasa disebut dengan GLS. Sehingga, diharapkan sekolah mampu mengembangkan kebijakan pemerintah melalui pedoman gerakan literasi yang nantinya mampu diimplementasikan dan dikembangkan sesuai situasi dan kondisi sekolah. Penelitian ini membahas bagaimana kebijakan gerakan literasi dalam meningkatkan minat baca peserta didik di SMA Al-Huda Tuban. Penelitian ini merupakan penelitian kuantitatif. Sampel penelitian adalah siswa kelas XI berjumlah 47 siswa. Pengumpulan data dengan metode observasi, angket, wawancara, dan dokumentasi. Uji keabsahan data dengan menggunakan uji validitas dan uji reliabilitas. Analisis data dengan analisis deskriptif, uji hipotesis, analisis Product moment. Hasil penelitian menjelaskan adanya implementasi dan strategi yang baik mengarah kepada meningkatkan minat baca peserta didik. Hasil penelitian menunjukkan: (1) Kebijakan gerakan literasi di SMA Al-Huda Tuban cukup baik Jumlah responden paling banyak diantara pengelompokan nilai dari jumlah responden 47 yaitu diperoleh nilai 71-75 dengan 12 responden. (2) Minat baca di SMA Al-Huda Tuban tinggi memiliki frekuensi tertinggi yaitu 15 responden dengan nilai mean 78,463 modus 80 dan median 80. (3) Program Gerakan Literasi Sekolah terhadap Minat Baca Siswa di SMA Al-Huda Tuban, dengan rxy $=0,759$ dengan nilai signifikansi 0,566 atau $0,56 \%$.
\end{abstract}

Kata Kunci : : Manajemen; publik; pendidikan. 


\begin{abstract}
Abstrac; The climate of literacy in education is increasingly being voiced. To realize the National Literacy Movement, both in the realm of schools, families, and communities, a comprehensive and well-planned strategy is needed. Seeing the importance of reading culture and the lack of interest in reading in Indonesia, the government has launched a literacy movement. The implementation of this strategy is by creating the School Literacy Movement carried out by the Government in the field of education, namely the Law of the Republic of Indonesia Number 20 of 2003 concerning the National Education System. In Chapter III article 4 paragraph 5 , it reads "Education is carried out by developing a culture of reading, writing and arithmetic for all members of the community", making policies regarding reading interest. Interest in reading is expected to grow and develop in these students, guided by the policy of the school literacy movement or commonly referred to as GLS. Thus, it is hoped that schools will be able to develop government policies through literacy movement guidelines which will be able to be implemented and developed according to the situation and conditions of the school. This study discusses how the literacy movement policy in increasing students' interest in reading at SMA Al-Huda Tuban. This research is a quantitative research. The research sample is class XI students totaling 47 students. Collecting data with the methods of observation, questionnaires, interviews, and documentation. Test the validity of the data by using the validity test and reliability test. Data analysis with descriptive analysis, hypothesis testing, Product moment analysis. The results of the study explain that there is a good implementation and strategy that leads to increasing students' reading interest. The results showed: (1) The literacy movement policy at SMA Al-Huda Tuban was quite good. The number of respondents was the most among the grouping of scores from the number of respondents 47 , which was obtained a score of 71-75 with 12 respondents. (2) Reading interest in high school Al-Huda Tuban has the highest frequency, namely 15 respondents with a mean value of 78.463 mode 80 and a median of 80. (3) School Literacy Movement Program on Student Interest in Reading at SMA Al-Huda Tuban, with rxy $=0.759$ with a significance value of 0.566 or $0.56 \%$.
\end{abstract}

Abstract : : Mangement; public; education.

Pendidikan tidak bisa lepas dengan membaca, menulis, medengarkan dan berhitung. Semua itu adalah proses didalam menambahkan pengetahuan dan keilmuan dalam masyarakat tentunya diperlukan kesadaran mengenai budaya membaca. Pemerintah dalam bidang pendidikan yaitu Undang-Undang Republik Indonesia Nomor 20 Tahun 2003 tentang Sistem Pendidikan Nasional. Pada Bab III pasal 4 ayat 5 , berbunyi "Pendidikan diselenggarakan dengan mengembangkan budaya membaca, menulis dan berhitung bagi segenap warga masyarakat" yang di implementasikan berupa strategi kebijakan literasi sekolah dan terdapat pedoman pelaksanaan yang bisa menjadi acuan sekolah dalam meningkatkan minat baca khususnya dan literasi pada umumnya.

Minat baca yang diharapkan tumbuh dan berkembang pada peserta didik ini, dipandu dengan adanya kebijakan gerakan literasi sekolah, gerakan ini dilakukan oleh sekolah pada setiap awal proses pembelajaran di kelas selama 15 menit, guna menggapai suatu tujuan yakni minat siswa dalam membaca meningkat, maka perlu adanya dorongan dan strategi yang diberikan pemerintah yakni gerakan literasi Nasional. Gerakan ini merupakan implementasi dari peraturan menteri pendidikan dan kebudayaan nomor 23 tahun 2015 tentang penumbuhan budi pekerti. Pemerintah menyadari bahwa sekolah

\footnotetext{
${ }^{1}$ Undang-Undang Republik Indonesia Nomor 20 Tahun 2003
} 
seharusnya menjadi tempat nyaman bagi siswa dan guru. ${ }^{2}$ Apalagi jika kita mengetahui minat baca masyarakat Indonesia dinilai masih rendah dibandingkan dengan Negara lain. UNESCO mencatat pada 2012 indeks minat baca di Indonesia baru mencapai 0,001 artinya dalam 1000 orang hanya ada satu orang yang berkegiatan membaca. walaupun mungkin ketidak tertarikan pada kegiatan membaca tidak hanya karena minat baca yang minim tapi, karena ketersediaan buku yang bisa merangsang mereka untuk membaca memang kurang.

Menurut penelitian dari ASEAN masyarakat sedang berkembang masih kental dengan budaya mengobrol dibandingkan dengan budaya membaca (chatting society). Hal ini bisa kita buktikan berapa jumlah orang yang memanfaatkan waktu luangnya untuk membaca, semisal di kendaraan umum, antrian, hanya duduk diam tanpa melakukan aktivitas apapun. Selain itu data Bank Dunia menyebutkan pada awal tahun 2000 ditemukan masyarakat Indonesia lebih cenderung menggunakan televisi sebagai media memperoleh informasi bukan melalui media buku. Indikator rendahnya minat baca juga bisa dilihat dari jumlah buku yang terbit di Indonesia. ${ }^{3}$ Padahal, suatu bangsa bisa disebut bangsa yang maju jika tingkat minat baca, budaya berwacana, serta menulis masyarakatnya aktif.

Di dalam Al-qur'an sebagai pedoman umat islam juga terdapat perintah untuk mewajibkan kita membaca, Q.S. Al-Alaq diawali dengan kata iqra' yang memiliki arti "bacalah" dari kata qara'a yang artinya membaca atau bacaan. Sehingga, Al-Quran sebagai kalam Allah yang diturunkan melalui Nabi Muhammad memiliki perintah kepada hambaNya untuk membaca dari fi'il amar iqra'. Membaca di buku dan membaca semua ciptaanNya, semua kejadian dan mampu memeroleh pelajaran, pengetahuan dan wawasan didalamnya. Sehingga dengan membaca ilmu, wawasan dan pengetahuan semakin meluas dan semakin mampu disebarkan sebagai amal. Dalam tahapan pelaksanaan GLS tentunya dilaksanakan secara bertahap dengan mempertimbangkan kesiapan sekolah di seluruh Indonesia. Kesiapan ini mencakup kesiapan kapasitas sekolah (ketersediaan fasilitas, bahan bacaan, sarana, prasarana literasi), kesiapan warga sekolah, dan kesiapan sistem pendukung lainnya (partisipasi publik, dukungan kelembagaan, dan perangkat kebijakan yang relevan). ${ }^{4}$ Gerakan literasi sekolah hadir sebagai solusi untuk menanggulangi rendahnya minat baca siswa sehingga, mampu tumbuh dan berkembang dengan baik. Semua itu terdapat tahapan yang perlu dilakukan seperti tahap pembiasaan, pembelajaran dan pengembangan.

Literasi adalah kemampuan mengakses, memahami, dan menggunakan sesuatu secara cerdas melalui berbagai aktivitas, antara lain membaca, melihat, menyimak, menulis, dan berbicara. GLS merupakan suatu usaha atau kegiatan yang bersifat partisipatif dengan melibatkan warga sekolah (siswa, guru, kepala sekolah, tenaga kependidikan, pengawas sekolah, komite sekolah, orang tua atau wali murid siswa), akademisi, penerbit.

Kern dalam Yusuf \& Hayat mengemukakan bahwa terdapat 7 prinsip pendidikan berbasis literasi di sekolah yaitu:

1. Literasi melibatkan interpretasi

Penulis/pembicara dan pembaca/pendengar berpartisipasi dalam tindak interpretasi, yakni: penulis/pembicara menginterpretasikan dunia (peristiwa, pengalaman, gagasan, perasaan, dan lain-lain), dan pembaca/ pendengar kemudian mengiterpretasikan interpretasi penulis/pembicara dalam bentuk konsepsinya sendiri tentang dunia.

2. Literasi melibatkan kolaborasi

Terdapat kerjasama antara dua pihak yakni penulis/pembicara dan membaca/pendengar. Kerjasama yang dimaksud itu dalam upaya mencapai suatu pemahaman bersama. Penulis/pembicara memutuskan apa yang harus ditulis/dikatakan atau yang tidak

\footnotetext{
2 Pedoman Gerakan Nasional Literasi Bangsa (Bidang Pembelajaran dan Pusat Pembinaan Bahasa Kementrian Pendidikan dan Kebudayaan, 2016), 1.

${ }^{3}$ Aliyatin Nafisah, Arti Penting Perpustakaan Bagi Upaya Peningkatan Minat Baca Masyarakat, jurnal perpustakaan librariya, Vol 2 No. 2 (Juli, 2014), 3.

4 Thamrin Kasman dan Wowon Widaryat, Design Induk Ggerakan Literasi Sekolah, (Jakarta: Direktorat Jenderal Pendidikan Dasar dan Menengah Kementerian Pendidikan dan Kebudayaan, 2016), 17.
} 
perlu ditulis/dikatakan berdasarkan pemahaman mereka terhadap pembaca dan pendengarnya. Sementara pembaca atau pendengar mencurahkan motivasi, pengetahuan, dan pengalaman mereka agar dapat membuat teks penulis bermakna.

3. Literasi melibatkan konvensi

Orang-orang membaca dan menulis atau menyimak dan berbicara itu ditentukan oleh konvensi/ kesepakatan kultural (tidak universal) yang berkembang melalui penggunaan dan dimodifikasi untuk tujuan-tujuan individual. Konvensi disini mencakup aturan-aturan bahasa baik lisan maupun tertulis.

4. Literasi melibatkan pengetahuan kultural.

Membaca dan menulis atau menyimak dan berbicara berfungsi dalam sistem-sistem sikap, keyakinan, kebiasaan, cita-cita, dan nilai tertentu. Sehingga orang-orang yang berada di luar suatu sistem budaya itu rentan/ beresiko salah dipahami oleh orang-orang yang berada dalam sistem budaya tersebut.

5. Literasi melibatkan pemecahan masalah.

Karena kata-kata selalu melekat pada konteks linguistik dan situasi yang melingkupinya, maka tindak menyimak, berbicara, membaca, dan menulis itu melibatkan upaya membayangkan hubungan di antara kata-kata, frase-frase, kalimat-kalimat, unit-unit makna, teks-teks, dan dunia. Upaya membayangkan/memikirkan/mempertimbangkan ini merupakan suatu bentuk pemecahan masalah.

6. Literasi melibatkan refleksi dan refleksi diri.

Pembaca/ pendengar dan penulis/ pembicara memikirkan bahasa dan hubungannya dengan dunia dan diri mereka sendiri. Setelah mereka berada dalam situasi komunikasi mereka memikirkan apa yang telah mereka katakan, bagaimana mengatakannya, dan mengapa mengatakan hal tersebut.

7. Literasi melibatkan penggunaan bahasa.

Literasi tidaklah sebatas pada sistem-sistem bahasa (lisan/ tertulis melainkan mensyaratkan pengetahuan tentang bagaimana bahasa itu digunakan baik dalam konteks lisan maupun tertulis untuk menciptakan sebuah wacana/diskursus. Komponen literasi informasi yang terdiri atas literasi dasar, literasi perpustakaan, literasi media, literasi teknologi, dan literasi visual. Komponen literasi tersebut dijelaskan sebagai berikut.

\section{a. Literasi Dasar (Basic Literacy)}

Literasi Dasar (Basic Literacy), yaitu kemampuan untuk mendengarkan, berbicara, membaca, menulis, dan menghitung (counting) berkaitan dengan kemampuan analisis untuk memperhitungkan (calculating), mempersepsikan informasi (perceiving), mengomunikasikan, serta menggambarkan informasi (drawing) berdasarkan pemahaman dan pengambilan kesimpulan pribadi.

\section{b. Literasi Perpustakaan (Library Literacy)}

Literasi Perpustakaan (Library Literacy), antara lain memberikan pemahaman cara membedakan bacaan fiksi dan nonfiksi, memanfaatkan koleksi referensi, memudahkan dalam menggunakan perpustakaan, memahami penggunaan katalog dan pengindeksan, hingga memiliki pengetahuan dalam memahami informasi.

\section{c. Literasi Media (Media Literacy)}

Literasi Media (Media Literacy), yaitu kemampuan untuk mengetahui, media televisi berbagai bentuk media yang berbeda, seperti media cetak, media elektronik (media radio), media digital (media internet), dan memahami tujuan penggunaannya.

\section{d. Literasi Teknologi (Technology Literacy)}

Literasi Teknologi (Technology Literacy), yaitu kemampuan memahami kelengkapan yang mengikuti teknologi seperti peranti keras (hardware), peranti lunak (software), serta etika dan etiket dalam memanfaatkan teknologi. 
Author (Garamond 11)

\section{e. Literasi Visual (Visual Literacy)}

Literasi Visual (Visual Literacy), adalah pemahaman tingkat lanjut antara literasi media dan literasi teknologi, yang mengembangkan kemampuan dan kebutuhan belajar dengan memanfaatkan materi visual dan audiovisual secara kritis dan bermartabat. ${ }^{5}$

Gerakan literasi sekolah adalah salah satu upaya yang dilakukan pemerintah Indonesia pada khususnya, di kabupaten Tuban. Melalui peraturan menteri pendidikan dan kebudayaan melakukan gerakan berupa literasi sekolah yang dilaksanakan 15 menit sebelum pelajaran dilakukan pada awal pembelajaran atau sebelum jam pertama dimulai. Diharapkan melalui gerakan literasi sekolah ini dapat meningkatkan kualitas Indonesia dengan meningkatkan minat dan baca peserta didik di sekolah. Akademisi, penerbit, media masa, masyarakat dan pemangku kepentingan di bawah koordinasi Direktorat Jenderal Pendidikan Dasar dan Menengah Kementerian Pendidikan dan Kebudayaan. ${ }^{6}$ Memiliki peran penting juga dalam menjalankan dan mendukung program literasi sekolah ini sehingga dapat tercipta tujuan yakni meningkat kan minat baca di Indonesia ini.

Di dalam panduan Gerakan Literasi Sekolah SMA dijelaskan untuk menindak lanjuti amanat UUD 1945 dan Permendikbud Nomor 23 Tahun 2015 di atas, SMA di Indonesia wajib melaksanakan program GLS. Gerakan ini membina dan mengembangkan budaya baca di sekolah dengan program yang melibatkan seluruh warga sekolah (whole-school). Selanjutnya, diharapkan terbentuk masyarakat literat yang melibatkan rumah-sekolah-masyarakat (home-school-community partnership). Setelah dilaksanakannya literasi sekolah sebagai sebuah gerakan nasional pada Februari 2016, berikutnya dicanangkan Gerakan Literasi Nasional (GLN) pada Oktober 2017. Pada perkembangan selanjutnya, ditetapkan Permendikbud Nomor 20 Tahun 2018 tentang Penguatan Pendidikan Karakter pada Satuan Pendidikan Formal. Kegiatan GLS tidak lepas dari penguatan pendidikan karakter, pembelajaran Abad XXI yang mencakup keterampilan berpikir kritis, kreatif, komunikatif, kolaboratif. Selain itu, terkait literasi itu sendiri, yaitu penguasaan enam literasi dasar (baca-tulis, digital, numerasi, finansial, sains, serta budaya dan kewargaan).

Kegiatan literasi juga merupakan salah satu butir dalam komponen Standar Kompetensi Lulusan (SKL) yang dinilai oleh Badan Akreditasi Nasional Sekolah Menengah (BAN SM) melalui instrumen akreditasi sekolah pada nomor 33. Instrumen tersebut menilai kegiatan pembiasaan melalui gerakan literasi yang meliputi perencanaan dan penilaian program literasi, waktu yang cukup untuk kegiatan literasi, membaca buku, lomba terkait literasi, memajang karya tulis, penghargaan berkala untuk peserta didik, dan pelatihan literasi. Dengan demikian, sekolah wajib melaksanakan kegiatan literasi. Mengacu pada tujuan menumbuhkembangkan kebiasaan membaca, pada tahun 2016 digulirkan program Gerakan Literasi Sekolah (GLS) di 102 SMA di seluruh Indonesia. Gerakan ini diprogramkan oleh Direktorat Pembinaan SMA untuk membina peningkatan minat membaca peserta didik SMA. Pada pelaksanannya, sekolah bersama dengan pemangku kepentingan lainnya memberikan bantuan berupa fasilitas dan dorongan untuk menggerakkan budaya membaca peserta didik. ${ }^{7}$

Keberhasilan program GLS memerlukan panduan yang dapat dimanfaatkan kepala sekolah, guru, dan tenaga kependidikan sebagai sumber inspirasi dalam mewujudkan praktik-praktik baik yang didokumentasikan dan dapat diadopsi atau diadaptasikan sesuai konteks sekolah-sekolah yang senada sesuai dengan situasi dan kondisi sekolah sehingga pedoman itu dapat dimanfaatkan sebaik mungkin dalam rangka menumbuhkan minat baca siswa di sekolah. Variasi kegiatan dapat berupa perpaduan pengembangan ketrampilan reseptif maupun produktif. GLS (Gerakan Literasi Sekolah) merupakan sebuah upaya yang dilakukan secara menyeluruh untuk menjadikan sekolah sebagai organisasi pembelajaran yang warganya literat sepanjang hayat melalui pelibatan publik. $^{8}$

\footnotetext{
$5 \quad$ Ibid., 5.

${ }^{6}$ KEMENDIKBUD, Panduan Literasi Sekolah Di Sekolah Menengah Pertama (Jakarta: KEMENDIKBUD, 2016$), 2$.

${ }^{7}$ Marni Hartati et al., Panduan GLS SMA (Jakarta: direktorat pembinaan sekolah menengah atas direktorat jenderal pendidikan dasar dan menengah kementerian pendidikan dan kebudayaan, 2019), 2.

${ }^{8}$ Sutrianto, panduan gerakan literasi sekolah di sekolah menengah atas (Jakarta: direktorat pembinaan sekolah menengah atas, 2011), 2.
} 
Implementasi penumbuhan budaya literasi di sekolah berupa Program GLS memerlukan langkahlangkah. ${ }^{9}$ Didalam pelaksanaan gerakan literasi sekolah tentunya memiliki banyak persiapan untuk bisa menerapkannya di sekolah. Hal-hal yang perlu dipersiapkan yakni rapat koordinasi antara warga sekolah, pembentukan tim literasi perencanaan sosialisai, persiapan sarana dan prasarana dimana memiliki kode etik tersendiri dari pemerintah yang harus dilalui kemudian pelaksanaan, pemantauan dan evaluasi. Semua itu perlu kerjasama dan perhatian seluruh warga sekolah dalam semua managemen yang ada mulai dari planning, organizing, actuating, controlling hingga evaluasi baik evaluasi jangka pendek ataupun jangka panjang guna mengoptimalkan sistem yang kuat. Semestinya pegiat taman bacaan masyarakat, yang telah teruji komitmennya dalam penyelenggaraan kegiatan literasi, dilibatkan dalam pengelolaan perpustakaan. Dengan melibatkan pegiat literasi, atmosfer perpustakaan akan lebih hidup. Perpustakaan tak lagi sekedar tempat membaca dan meminjam buku. Lebih dari itu, ia menjadi pusat belajar dan interaksi masyarakat yang ingin maju melalui beragam kegiatan literasi, di antaranya bedah buku, diskusi tentang buku, dan festival. ${ }^{10}$

\section{Methode/ Metode}

Penelitian ini menggunakan penelitian kuantitatif dengan desain penelitian korelasi. Penelitian ini dilakukan di SMA Al-Huda Tuban yang beralamatkan Jl. Letda Suctipto, kelurahan Perbon Kecamatan Tuban, Kabupaten Tuban Jawa Timur. Penelitian ini dilakukan pada tanggal 21 Juli 2020. Sedangkan objek penelitian dari penelitian ini adalah kebijakan program GLS dan minat baca siswa. Subjek dari program GLS adalah kepala sekolah, Tim GLS dan pustakawan, sedangkan yang mengarah pada pelaksanaan program GLS adalah peserta didik. Dalam penelitian ini peneliti memfokuskan pengambilan sampel pada kelas IX karena dirasa sudah merasakan kebijakan literasi dari kelas X setelah melaksakan wawancara kelas IX menjadi rekomendasi dari tim GLS atas pertimbangan apabila kelas X masih pendaftran tahun ajaran baru, dan kelas XII fokus belajar guna mempersiapkan kelulusan sehingga akan lebih valid dalam pengisian angket. ${ }^{11}$

Proses penelitian terbagi menjadi tiga tahapan, yaitu pra penelitian dimana pada tahapan ini, penulis melakukan studi literatur dan observasi sebagai dasar penelitian. Penelitian merupakan tahapan selanjutnya yang peneliti lakukan dengan membagikan angket kepada responden untuk mengisi angket/kuesioner mengenai pengaruh kebijakan program gerakan literasi sekolah terhadap minat baca siswa di SMA Al-Huda Tuban. Penyusunan laporan merupakan tahap akhir dalam proses penelitian ini. Teknik Analisis Data dalam penelitian ini, menggunakan dua analisis yaitu: Analisis Deskriptif, yaitu analisis yang digunakan untuk mengetahui jumlah rata-rata tentang deskripsi pengaruh kebijakan GLS terhadap minat peserta didik di SMA Al-Huda Tuban.

Teknik analisis data pada penelitian ini menggunakan statistik deskriptif, yang mana penyajian data dapat melalui perhitungan Mean. Mean merupakan teknik penjelasan kelompok yang didasarkan atas nilai rata-rata dari kelompok tersebut. ${ }^{12}$ Pengujian ini bertujuan untuk menguji variabel bebas $(\mathrm{X})$ terhadap variabel terikat $(\mathrm{Y})$. Dengan menggunakan uji ini kita dapat mengetahui apakah ada pengaruh dari kebijakan program GLS terhadap minat baca peserta didik di SMA Al-Huda Tuban.

Teknik statistik inferensial Statistik inferensial digunakan peneliti untuk menetapkan sejauh manakah ia dapat menyimpulkan hasil penelitian dari data yang diperoleh dalam kelompok subjek yang terbatas (sampel) bagi populasi penelitian.

Adapun rumus yang digunakan untuk menguji kebenaran hipotesis penelitian ini yaitu sebagai berikut:

a. Analisis Regresi Sederhana dengan menggunakan Rumus :

\footnotetext{
${ }^{9}$ Panduan Gerakan Literasi Sekolah Di SMA (Jakarta: Direktorat Jendral Pendidikan Dasar dan Menengah, 2019), 4-8.

${ }^{10}$ Billy Antoro, Gerakan Literasi Sekolah Dari Pucuk Hingga Akar (Jakarta: Direktorat Jenderal Pendidikan Dasar dan Menengah Kementerian Pendidikan dan Kebudayaan, 2017), 30-31.

${ }^{11}$ Laily Muhlishoh S.Pd, Wawancara, Tuban 8 Januari 2020. Pada 15.30-16.00 WIB

${ }^{12}$ Sugiono, Statistika untuk Penelitian(Bandung: ALFABETA, cet.26, 2015), 49
} 
Author (Garamond 11)

$$
\mathrm{Y}=a+b X
$$

Keterangan:

$Y=$ Subjek dalam variabel dependen yang diprediksikan

$a=$ Bilangan Konstan

$b=$ Angka arah atau koefisien regresi, yang menunjukkan angka peningkatan

Ataupun penurunan variabel dependen yang didasarkan pada variabel independen. Bila $b(+)$ maka naik, Bila $b(-)$ maka terjadi penurunan $X=$ Subjek pada variabel independent yang mempunyai nilai tertentu. Data yang sudah diperoleh kemudian dianalisis dengan langkah-langkah sebagai berikut: 1) melakukan rekapitulasi data yang diperoleh dari angket ke dalam $M s$. Excel; 2) mencari skor total dari setiap variabel; 3) mencari rerata dari setiap variabel; 4) mengkategorikan setiap variabel. Dari hasil yang telah di jawab oleh peserta didik, yaitu dengan kelompok kategori rendah, kurang, sedang, tinggi. Teknik analisis data pada penelitian ini menggunakan statistik deskriptif, yang mana penyajian data dapat melalui perhitungan Mean. Mean merupakan teknik penjelasan kelompok yang didasarkan atas nilai rata-rata dari kelompok tersebut. Pengujian ini bertujuan untuk menguji variabel bebas (X) terhadap variabel terikat $(\mathrm{Y})$. Dengan menggunakan uji ini kita dapat mengetahui apakah ada pengaruh dari kebijakan program GLS terhadap minat baca peserta didik di SMA Al-Huda Tuban. Urutan penyusunan nilai tabel kategori sebagai berikut: 1) menghitung skor minimal ideal 2) menghitung ratarata ideal 3) menentukan rentang skor setiap kategori 4) Jumlah kelas interval dan menghitung jumlah frekuensi terendah hingga tertinggi dari soal yang diberikan dari setiap variabel. Untuk mengetahui persebaran frekuensi, ditentukan terlebih dahulu panjang kelas intervalnya, dengan cara sebagai berikut:

1) Menghitung rentang jarak interval dengan menggunakan rumus sebagai berikut:

$\mathrm{R}=$ skor tertinggi jumlah butir - skor terendah jumlah butir

$\mathrm{R}=(85)-(51)=34$

2) Menghitung banyak kelas $(\mathrm{K})$ aturan Sturges:

$\mathrm{K}=1+[3,3 \cdot \log n\rceil=\lceil 1+3,3 \log 47\rceil$

$\mathrm{K}=1+[3,3.1,6]$

$\mathrm{K}=1+[5,281 \approx 1+6 \approx 7$

$\mathrm{K}=$ banyak kelas 7 kelas

3) Mencari panjang kelas interval (p) dengan rumus:

$\mathrm{P}=\frac{R}{K}=\frac{34}{7}=4,85=5$

4) Menghitung rentang jarak interval dengan menggunakan rumus sebagai berikut:

$\mathrm{R}=$ skor tertinggi jumlah butir - skor terendah jumlah butir

$\mathrm{R}=(85)-(51)=34$

5) Menghitung banyak kelas $(\mathrm{K})$ aturan Sturges:

$\mathrm{K}=1+[3,3 \cdot \log n\rceil=\lceil 1+3,3 \log 47\rceil$

$\mathrm{K}=1+[3,3.1,6]$

$\mathrm{K}=1+[5,28] \approx 1+6 \approx 7$

$\mathrm{K}=$ banyak kelas 7 kelas

6) Mencari panjang kelas interval (p) dengan rumus:

$\mathrm{P}=\frac{R}{K}=\frac{34}{7}=4,85=5$

\section{Hasil Penelitian Dan Pembahasan}

SMA Al-Huda Tuban merupakan salah satu sekolah di Tuban yang menerapkan kebijakan GLS yang baik dan mampu memberikan efek baik bagi sekolah khususnya peserta didik setelah observasi dan diteliti sekolah ini mampu menjuarai lomba perpustakaan terbaik se kabupaten Tuban dan mampu memiliki buku kumpulan cerpen siswa yakni SMA Al-Huda Tuban yang sudah melaksanakan GLS semenjak tahun 2016 dengan kondisi siswa yang minat bacanya baik, akan tetapi belum merata ke seluruh peserta didik. Usaha mengimplementasikan program sekolah sedikit demi sedikit terpenuhi baik 
bidang sarana prasarana ataupun pelaksanaan strategi. Mengoptimalkan dan mengevaluasi di setiap kebijakan dengan terus menerus maka lambat laun minat baca siswa semakin membaik. Prinsip-prinsip kegiatan literasi dari tahap pembiasaan, pengembangan dan pembelajaran mampu dilaksanakan dengan sangat baik dan sangat perencanaan yang strategis seperti:

1. Guru menetapkan waktu 15 menit membaca setiap hari yang dilaksanakan sebelum pelajaran

2. Buku yang dibaca/dibacakan adalah buku non pelajaran

3. Buku yang dibaca/dibacakan adalah pilihan peserta didik sesuai minat dan kesenangannya.

4. Kegiatan membaca/membacakan buku di tahap ini tidak diikuti oleh tugas-tugas yang bersifat tagihan/penilaian yang akan di rekap di jurnal literasi milik setiap siswa

5. Terbentuknya Tim Literasi Sekolah (TLS) yang tangguh

6. Bedah Buku

7. Penghargaan duta baca tiap tahun (Reading Award)

8. Menulis karya antologi cerpen tiap tahun

9. Mengadakan stand baca yang digunakan untuk promosi (buku baru di perpustakaan yang dipamerkan di depan kelas siswa setiap 3 bulan sekali).

10. Setiap kelas memiliki perpustakaan kelas

11. Pemasangan mading yang bergilir, poster literasi. ${ }^{13}$

Program Gerakan Literasi Sekolah yang dilaksanakan di SMA Al-Huda Tuban berjalan sesuai dengan panduan dari direktorat jenderal pendidikan sekolah menengah atas kementerian pendidikan dan kebudayaan. Program yang dilaksanakan masih berjalan sesuai pedoman pemerintah yang didesaign sebaik mungkin sehingga mampu dikemas dan dilaksanakan dengan baik Agar lebih masif, program GLS melibatkan partisipasi publik,

seperti pegiat literasi, orang tua, tokoh masyarakat, dan profesional. Keberhasilan berliterasi di sekolah perlu diupayakan melalui kegiatan-kegiatan yang menumbuhkan budaya literasi. Mengacu pada lima aspek strategi yang dapat mendukung terlaksananya Gerakan Literasi Nasional, yaitu kapasitas fasilitator, jumlah dan ragam sumber belajar bermutu, akses terhadap sumber belajar dan cakupan peserta belajar, pelibatan publik, serta tata kelola. Kelima strategi ini diterapkan di setiap ranah literasi dengan kebutuhan dan karakteristik masing-masing. ${ }^{14}$ yang sudah ditetapkan di SMA Al-Huda Tuban tentunya dengan mempertahaankan nilai-nilai yang dipegang dan mengembangkannya sesuai dengan situasi dan kondisi di sekolah. Dimana berupaya mampu meningkatkan minat baca siswa.

Perpustakaan sekolah menjadi tempat yang tidak bisa disepelekan di sekolah dimana perpustakaan sekolah memiliki pengaruh dalam menumbuhkan minat baca siswa. Fasilitas di perpustakaan sudah lengkap seperti melengkapi buku yang dibutuhkan di perpustakaan sekolah agar lengkap dan menarik, rak buku, kondisi perpustakaan yang nyaman fasilitas yang menunjang lainnya seperti yang ada pada tahun 2015-2016 SMA Al Huda Boarding Schoolsudah melakukan proses pengolahan bahan pustaka, tetapi masih manual. Artinya, masih belum menggunakan aplikasi tertentu dan hanya menggunakan MS. Word saja dan pada tahun 2017 perpustakaan SMA Al Huda Boarding School mampu mengolah bahan pustaka dengan mengembangkan layanan berbasis teknologi informasi. Sebuah layanan dengan mengupayakan otomasi perpustakaan yang dibimbing Dinas Perpustakaan dan Kearsipan Kabupaten Tuban melalui pelatihan penggunaan aplikasi inlislite. Otomasi tersebut di antaranya meliputi entri data buku, cetak label, entri anggota, cetak kartu anggota, transaksi (baca, pinjam, pengembalian buku), dan laporan. SMA Al-Huda Boarding Schoolsudah memberitahukan keberadaan perpustakaan dengan cara registrasi ke perpustakaan Nasional RI untuk memperoleh Nomor Pokok Perpustakaan (NPP) dengan dibuktikan adanya NPP 3523161 E200000 yang kini sudah dimiliki. Dengan adanya aplikasi inlislite tersebut SMA Al Huda Boarding School dapat mengikuti

\footnotetext{
${ }^{13}$ Ines Nasa Charmarica,S. Ip Wawancara, Tuban 9 Januari 2020. Pada 15.00-16.30 Wib

${ }^{14}$ Penguatan Kapasitas Fasilitator Fasilitator literasi merupakan ujung tombak gerakan literasi yang membantu dan mendorong masyarakat Indonesia dalam menumbuhkembangkan budaya literasi pada ekosistem pendidikan. Baca Hikmat Panduan Gerakan Literasi Nasional (Jakarta: Kementerian Pendidikan dan Kebudayaan, 2017), 17-19
} 
perkembangan zaman dan dapat bersaing dengan sekolah negeri di Kabupaten Tuban. Kendala yang ada ialah perpustakaan mini atau disebut sudut baca di kelas siswa dapat memanfaatkan waktu waktu tertentu untuk membaca di kelas ketika jam kosong akan tetapi buku di perpustakaan mini yang ada di kelas sering hilang dan akhirnya pada tahun 2018-2019 pengadaan perpustakaan mini di sekolah diberhentikan, kendala itu yang menjadi penghambat dalm tahap pembiasaan akan tetapi peran perpustkaan sekolah semakin dijaga guna mengatur keseimbangan.

Pelaksanaan program Gerakan Literasi Sekolah melibatkan warga sekolah seperti, guru, kepala sekolah, siswa, orang tua, tenagapendidikan, pengawas sekolah, dan komite

sekolah. Dengan melibatkan warga sekolah dapat berjalan dengan baik seperti koordinasi dengan warga sekolah misalnya, guru memberi arahan pada siswa untuk belajar ke perpustakaan, guru membimbing siswauntuk membaca 15 menit sebelum belajar. Pelaksanaan program gerakan literasi sekolah melalui koordinasi yang baik dari tim GLS dan warga sekolah mampu menjalankan roda keberjalanan literasi di sma al-huda dengan baik. Di dalam setiap pelaksanaan program tentunya memiliki kendala baik itu kecil ataupun besar dalam keberjalanan itu semua dengan strategi dan inovasi yang dilakukan semua hambatan itu tidak terlalu berarti.

Adapun hasil penelitian yang diperoleh berkaitan dengan pengaruh program gerakan literasi sekolah terhadap minat baca siswa yang dilihat dari komponen konteks, masukan, proses dan hasil akan dibahas sebagai berikut:

\section{a. Deskripsi Data Kebijakan Gerakan Literasi Sekolah (Variabel X)}

Data keterampilan membuka dan menutup pembelajaran diperoleh dari angket yang telah divalidasi. Angket tersebut terdiri dari 20 pernyataan yang dengan jenis pernyataan negatif dan penyataan positif. Pengukuran data tersebut menggunakan skala likert, sehingga diperoleh data skor interval terendah yaitu 51 dan skor interval tertinggi yaitu 85. Untuk mengetahui persebaran frekuensi, ditentukan terlebih dahulu panjang kelas intervalnya terkait kebijakan gerakan literasi sekolah Hasil uji hipotesisdapat dilihat pada tabel berikut

Tabel 1

Data hasil angket kebijakan gerakan literasi sekolah di SMA Al-Huda Tuban

\begin{tabular}{|c|c|c|c|c|c|}
\hline NO & INTERVAL & FREKUENSI & $\mathrm{Xi}$ & Fi.Xi & $\begin{array}{l}\text { Rata- } \\
\text { rata }\end{array}$ \\
\hline 1 & $51-55$ & 3 & 53 & 159 & \\
\hline 2 & $56-60$ & 2 & 58 & 116 & \\
\hline 3 & $61-65$ & 3 & 63 & 189 & \\
\hline 4 & $66-70$ & 6 & 68 & 408 & 127 \\
\hline 5 & $71-75$ & 12 & 73 & 876 & \\
\hline 6 & $76-80$ & 10 & 78 & 780 & \\
\hline 7 & $81-85$ & 11 & 83 & 913 & \\
\hline \multicolumn{2}{|c|}{ TOTAL } & 47 & & 5.969 & \\
\hline \multicolumn{2}{|c|}{ TOTAL } & 47 & \multicolumn{2}{|c|}{5.969} & \\
\hline
\end{tabular}

Kebijakan literasi sekolah menunjukkan hasil perhitungan dari hasil distribusi frekuensi, diketahui tabung 1 memiliki nilai 51-55 terdapat responden 3 memilih kebijakan GLS pada kategori rendah. Diketahui tabung 2 memiliki nilai 56-60 terdapat 2 responden memilih kebijakan GLS pada kategori rendah, diketahui tabung 3 memiliki nilai 61-65 Terdapat 3 responden dan seterusnya. Tabung nomor 5 dengan jumlah responden 12 dan tabung 6 memiliki responden 11 sehingga, dapat disimpulkan bahwa kebijakan literasi sekolah berada dalam kategori sedang dengan nilai 71-75. Hal itu menunjukkan bahwa, kebijakan literasi sekolah yang diterapkan di SMA Al-Huda cukup baik.

\section{b. Deskripsi Data Minat Baca Peserta Didik (Variabel Y)}

Data minat baca peserta didik diperoleh dari angket yang telah divalidasi. Angket tersebut terdiri dari 20 pernyataan yang dengan jenis pernyataan negatif dan penyataan positif. Pengukuran data tersebut menggunakan skala likert, sehingga diperoleh data skor interval terendah yaitu 51dan 
skor interval tertinggi yaitu 89. Untuk mengetahui persebaran frekuensi, ditentukan terlebih dahulu panjang kelas intervalnya, dengan cara sebagai berikut:

1. Menghitung rentang jarak interval dengan menggunakan rumus sebagai berikut:

$\mathrm{R}=$ skor tertinggi jumlah butir - skor terendah jumlah butir

$\mathrm{R}=(89)-(51)=38$

2. Menghitung banyak kelas $(\mathrm{K})$ aturan Sturges:

$$
\begin{aligned}
& K=1+[3,3 \cdot \log n\rceil=\lceil 1+3,3 \log 47\rceil \\
& K=1+[3,3.1,6\rceil \\
& K=1+[5,28\rceil \approx 1+6 \approx 7 \\
& K=\text { banyak kelas } 7 \text { kelas }
\end{aligned}
$$

3. Mencari panjang kelas interval $(\mathrm{p})$ dengan rumus:

$$
\mathrm{P}=\frac{R}{K}=\frac{38}{7}=5,42=6
$$

\begin{tabular}{|c|c|c|c|c|}
\hline NO & $\begin{array}{l}\text { KELAS } \\
\text { INTERVAL }\end{array}$ & FREKUENSI & $\mathbf{X i}$ & $\begin{array}{l}\text { Rata- } \\
\text { rata }\end{array}$ \\
\hline 1 & $51-56$ & 2 & 53,5 & \multirow{8}{*}{71,5} \\
\hline 2 & $57-62$ & 1 & 59,5 & \\
\hline 3 & 63-68 & 3 & 65,5 & \\
\hline 4 & $69-74$ & 12 & 71,5 & \\
\hline 5 & $75-80$ & 15 & 77,5 & \\
\hline 6 & $81-86$ & 13 & 83,5 & \\
\hline 7 & $87-92$ & 1 & 89,5 & \\
\hline \multicolumn{2}{|c|}{ TOTAL } & 47 & 500,5 & \\
\hline
\end{tabular}

Maka didapat panjang kelas intervalnya 38 sebanyak 7 kelas, dapat dilihat pada table berikut:

Tabel 2

Data hasil angket minat baca peserta didik di sekolah di SMA Al-Huda Tuban

minat baca peserta didik menunjukkan hasil perhitungan distribusi frekuensi, diketahui 1 responden memilih minat baca siswa pada kategori rendah. Terdapat 12 responden memilih minat baca siswa pada kategori sedang. 15 responden memilih minat baca siswa pada kategori sedang dengan nilai pengelompokan yang cukup baik yaitu 76-81. Serta terdapat 13 responden yang memilih minat baca siswa pada kategori tinggi yaitu dengan nilai 82-87. Sementara itu, jika dilihat dari nilai yang diperoleh, apabila di masukkan dalam tiga kategori diatas, berada pada interval 76-81 dalam kategori sedang dan nilai yang tinggi pada interval 82-87 dengan jumlah frekuensi 13 sehingga dapat disimpulkan bahwa minat baca siswa pada kategori tinggi.

peneliti juga menghitung jumlah pengunjung perpustakaan memiliki nilai pengunjung yang semakin meningkat. Berikut diagram jumalah pengunjung perpustakaan SMA Al-Huda Tuban. 


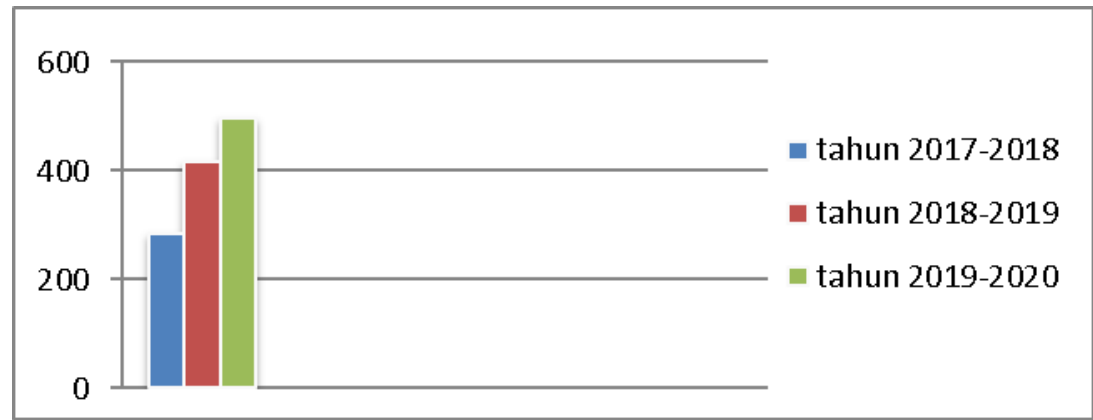

Dapat diketahui pada diagram 4.3 jumlah pengunjung pepustakaan pada tahun 2017-2018 jumlah pengunjung 283, pada tahun 2018-2019 jumlah pengunjung 417 dan pada tahun 2019-2020 jumlah pengunjung 498. Setiap tahunnya meningkat dan pada tahun 2019-2020 jumlah pengunjung memiliki nilai tertinggi.

\section{c. Pengaruh Kebijakan Program Gerakan Literasi Sekolah (GLS) Terhadap Minat Baca} Siswa

\section{a. Uji Reabilitas}

Penelitian ini menggunakan Uji Reabilitas Pengajuan reabilitas data dilakukan terhadap data kebijakan GLS dan minat baca peserta didik yang dilakukan dengan bantuan microsoft ecxel Berdasarkan analisis prasyarat yang diperoleh, maka kesimpulan hasil uji reabilitas dapat dilihat pada tabel di bawah ini.

\begin{tabular}{|l|l|}
\hline Regression Statistics & \\
\hline Multiple R & 0,759112184 \\
\hline R Square & 0,576251308 \\
\hline Adjusted R Square & 0,566834671 \\
\hline Standard Error & 5,272942706 \\
\hline Observations & 47 \\
\hline
\end{tabular}

Dari data diatas, nilai korelasi antara variabel $\mathrm{X}$ yang berbunyi kebijakan gerakan literasi sekolah dan $\mathrm{Y}$ yang berbunyi minat baca peserta didik. Dimana nilai korelasi $\mathrm{X}$ dengan $\mathrm{Y}$ adalah 0,759112 termasuk dalam kategori kuat menurut Sugiono 0,06-0,0799 termasuk dalam kategori kuat. ${ }^{15}$ Nilai adjusted $\mathrm{R}$ square atau nilai koefisien determinasi 0,566 atau $0,56 \%$. yang berarti bahwa $\mathrm{X}$ dapat menjelaskan $\mathrm{Y}$ sebesar 0,56 terdapat hubungan linier antara dua variabel, sisanya dipengaruhi faktor lain seperti yang telah diulas di atas terkait tujuan kegiatan literasi pada tahap pengembangan belum sepenuhnya dilaksanakan, yang belum dilaksanakan dari tahap pembiasaan yaitu sudut baca dan perpustakaan mini atau perpustakaan kelas dan kegaiatan dalam tahap diskusi.

\section{b. Uji Hipotesis}

Pengujian hipotesis dalam penelitian ini juga menggunakan korelasi Product moment yang dilakukan untuk mengetahui sejauh mana pengaruh kebijakan gerakan literasi sekolah terhadap

Rumus Korelasi Pearson Product Moment:

$$
r_{x y}=\frac{\mathrm{N} \Sigma \mathrm{XY}-\left(\sum \mathrm{Y}\right)(\Sigma \mathrm{X})}{{\sqrt{\left(\mathrm{N} \sum \mathrm{X}^{2}-\left(\sum \mathrm{X}\right)^{2}\right)\left(\mathrm{N} \sum \mathrm{Y}^{2}-\left(\sum \mathrm{Y}\right)^{2}\right)}}^{8}}
$$

minat baca peserta didik.

Diketahui:

$\mathrm{N}=\quad 47$

${ }^{15}$ Suryana Yaya, Metode penelitian manajemen pendidikan (Bandung : CV pustaka setia, 2015), 283. 


$\begin{array}{ll}\sum \mathrm{xy}= & 265536 \\ \sum \mathrm{x}= & 3423 \\ \sum \mathrm{y}= & 3611 \\ \sum \mathrm{x}^{2}= & 253111 \\ \sum \mathrm{y}^{2}= & 280385 \\ \left(\sum \mathrm{x}\right)^{2}= & 11716929 \\ \left(\sum \mathrm{y}\right)^{2}= & 13039321\end{array}$

$$
\begin{array}{ll}
\mathrm{Rxy}= & \frac{119739,00}{157735,5791} \\
= & 0,759112184
\end{array}
$$

Berdasarkan hasil pernelitian melalui angket yang diuji reabilitas dan diketahui hasil korelasi produc moment untuk mengetahui sejauhmana pengaruh kebijakan gerakan literasi sekolah ditemukan nilai korelasi $\mathrm{X}$ dan $\mathrm{Y}$ adalah 0,759112 dengan presentase 0,75\% yang memiliki arti antara variabel $\mathrm{X}$ dan $\mathrm{Y}$ terdapat korelasi yang kuat atau tinggi dengan nilai signifikansi 0,566 atau $0,56 \%$ dengan nilai signifikansi $0,566>0,05$ yang ketentuannya bila Thitung lebih kecil dari $\mathrm{T}_{\text {tabel }}$ maka $\mathrm{H}_{0}$ diterima dan $\mathrm{H}_{1}$ ditolak dan begitupun sebaliknya bila Thitunglebih besar dari $\mathrm{T}_{\text {tabel }}$ maka $\mathrm{H}_{0}$ ditolak dan $\mathrm{H}_{1}$ diterima. Dan itu berarti ada pengaruh yang nyata (signifikan) antara kebijakan gerakan literasi sekolah dan minat baca peserta ddik di SMA Al-Huda Tuban. Seperti yang telah dijelaskan oleh kepala gerakan literasi sekolah terkait pengaruh kebijakan gerakan literasi sekolah sangat membantu dan mendorong peserta didik untuk membaca sehingga minat baca peserta didik di SMA Al-Huda Tuban meningkat. Selain itu kebijakan GLS mampu menjadi acuan dalam perbaikan fasilitas yang menunjang peserta didik dalam hal literasi. SMA Al-Huda Tuban selalu berusaha memperbaiki segala fasilitas ataupun strategi dalam pengembangan dan berjalannya gerakan literasi sekolah. Sesuai data yang telah dijelaskan jika nilai angket dari kebijakan cukup baik dan hasil angket minat baca peserta didik tinggi sehingga, mempengaruhi minat baca peserta didik. ${ }^{16}$ maka, ada "pengarub kebijakan gerakan literasi sekolab terbadap minat baca peserta didik di SMA Al-Huda Tuban” terbukti dan diterima.

Dari hasil perhitungan di atas ditemukan nilai dimana nilai korelasi X dengan Y adalah 0,759112 dengan persentase $0,75 \%$ yang memiliki arti antara variabel $\mathrm{X}$ dan variabel $\mathrm{Y}$ terdapat korelasi yang kuat atau tinggi. Dengan nilai signifikansi nilai adjusted $\mathrm{R}$ square atau nilai koefesien determinasi 0,566 atau 0,56\% menurut Sugiono bagi koefesian korelasi nilai 0,40-0,5999= sedang termasuk kategori sedang, yang berarti ada pengaruh yang nyata antara kebijakan gerakan literasi sekolah terhadap minat baca peserta didik di SMA Al-Huda Tuban.

\section{Kesimpulan}

Kebijakan gerakan literasi di SMA Al-Huda Tuban cukup baik. Berdasarkan hasil angket mengenai kebijakan gerakan literasi sekolah yang disebar pada 47 responden diperoleh skor tertinggi sebesar 85 skor dan skor terendah sebesar 51 dan nilai frekuensi tertinggi 71-75 jumlah frekuensi 12 dengan nilai mean 73,6 modus 81 dan median 75,5. Jumlah responden paling banyak diantara pengelompokan nilai yaitu 71-75 dengan 12 responden. Selain itu sekolah mampu menerapkan kebijakan yang fleksibel dan tepat sasaran dimana dalam setiap implementasi kebijakan GLS selalu memiliki strategi guna meningkatkan minat baca peserta didik. sehingga, kebijakan GLS mampu mendorong dan menjadi motivasi untuk peserta didik cinta literasi. Sebelumnya Minat baca di SMA AlHuda Tuban cukup baik akan tetapi belum sepenuhnya peserta didik minat membaca. Setelah diadakannya kebijakan gerakan literasi sekolah ini, minat baca peserta didik semakin meningkat terbukti dengan jumlah pengunjung perpustakaan yang setiap tahun semakin meningkat. Berdasarkan hasil

\footnotetext{
${ }^{16}$ Laily Muhlishoh, wawancara, Tuban 21 Juli 2020. Pada pukul 11.30-12.00
} 
angket minat baca siswa yang disebar pada 47 responden diperoleh skor tertinggi sebesar 89 skor terendah sebesar 51 dan nilai frekuensi tertinggi 75-80 memiliki frekuensi tertinggi yaitu 15 responden dengan nilai mean 78,463 modus 80 dan median 80 .

Pengaruh kebijakan literasi sekolah terhadap minat baca peserta didik memiliki nilai dalam kategori kuat. Setelah memberikan duan jenis angket yang berbeda pertanyakan terkait kebijakan GLS yang dilakukan sekolah (variabel $\mathrm{X}$ ) dan angket ke dua terkait minat bacap eserta didik setelah merasakan kebijakan GLS (variabel Y) dan Dari uji reabilitas terkait pengaruh kebijakan gerakan literasi sekolah terhadap minat baca peserta didik, nilai korelasi antara variabel X yang berbunyi "kebijakan gerakan literasi sekolah" dan Y yang berbunyi "minat baca peserta didik". Dimana nilai korelasi X dengan $\mathrm{Y}$ adalah 0,759112 termasuk dalam kategori kuat. Nilai adjusted $\mathrm{R}$ square atau nilai koefesien determinasi 0,566 atau 0,56\%. yang berarti bahwa X dapat menjelaskan $\mathrm{Y}$ sebesar 0,56 "terdapat hubungan linier antara dua variabel", sisanya dipengaruhi faktor lain dan berdasarkan persamaan korelasi dalam penelitian ini menggunakan rumus Product Moment mengatakan ada "pengaruh kebijakan gerakan literasi sekolah terhadap minat baca peserta didik di SMA Al-Huda Tuban", diterima.

\section{Daftar Kepustakaan}

Antoro, Billy. Gerakan Literasi Sekolah Dari Pucuk Hingga Akar. Jakarta: Direktorat Jenderal Pendidikan Dasar dan Menengah Kementerian Pendidikan dan Kebudayaan, 2017.

Arikunto, Suharsimi. prosedurpenelitian suatu pendekatan praktik. Jakarta: PT Rineka Cipta, 2013.

Hartati. Panduan GLS SMA. Jakarta: direktorat pembinaan sekolah menengah atas direktorat jenderal pendidikan dasar dan menengah kementerian pendidikan dan kebudayaan, 2019.

Kasman, Thamrin, DKK. desaign induk gerakan literasi sekolah. Jakarta: Direktorat Jenderal Pendidikan Dasar dan Menengah Kementerian Pendidikan dan Kebudayaan, 2016.

KEMENDIKBUD, Panduan Literasi Sekolah Di Sekolah Menengah Pertama. Jakarta: KEMENDIKBUD, 2016.

Muhlishoh, Laily. Wawancara. Tuban 21 Juli 2020. Pada pukul 11.00-12.00 WIB

Nafisah, Aliayatin. Arti Penting Perpustakaan bagi Upaya Minat Baca. Jurnal perpustakaan librariya, Vol. 02, No. 2 (Juli, 2014).

Nasa, Ines. Wawancara, Tuban 9 Januari 2020. Pada 15.00-16.30 WIB

Panduan Gerakan Nasional Literasi Bangsa Bidang Pembelajaran dan Pusat Pembinaan Bahasa Kementrian Pendidikan dan Kebudayaan, 2017.

Undang-Undang Republik Indonesia Nomor 20 Tahun 2003

Sutrianto. panduan gerakan literasi sekolah di sekolah menengah atas. Jakarta: direktorat pembinaan sekolah menengah atas, 2011. 